\title{
THE EFFECT OF JOB DESIGN AND CAREER DEVELOPMENT ON JOB SATISFACTION AND ORGANIZATIONAL COMMITMENTS OF PERSONNEL AT DIRECTORATE OF SAMAPTA REGIONAL POLICE OF WEST NUSA TENGGARA
}

\author{
Rina Yulianingsih \\ Magister of Management, Faculty of Economics and Business, \\ University of Mataram, Mataram, Indonesia \\ email: rina.yulianingsih@gmail.com
}

\section{Lalu Suparman}

Management, Faculty of Economics and Business, University of Mataram, Mataram, Indonesia corresponding author - email: lalusuparman77@gmail.com

\section{Mukmin Suryatni}

Management, Faculty of Economics and Business, University of Mataram, Mataram, Indonesia email: msuryatni@yahoo.com

DOI: $10.31364 / \mathrm{SCIRJ} / \mathrm{v} 9.106 .2021 . \mathrm{P0621XX}$

http://dx.doi.org/10.31364/SCIRJ/v9.i06.2021.P0621XX

\begin{abstract}
The aims of this research are: (1) To analyze the significance of the influence of Job Design on Job Satisfaction. (2) To analyze the significance of the influence of Career Development on Job Satisfaction. (3) To analyze the significance of the effect of the Job Design on Organizational Commitment. (4) To analyze the significance of the influence of Career Development on Organizational Commitment. (5) To analyze the significance of the effect of Job Satisfaction on Organizational Commitment. The type of research is causal associative. The data collection method uses a census. Respondents in this study were 95 Personnel at the Directorate of Samapta Regional Police of West Nusa Tenggara. The data collection tool used in this study was a questionnaire. Data analysis tool using SEMPLS analysis. The conclusions that can be drawn are (1) Job Design has a positive and significant effect on Organizational Commitment. (2) Career Development has a positive and significant effect on Organizational Commitment. (3) Job Design has a positive but insignificant effect on Job Satisfaction. (4) Career Development has a positive and significant effect on Job Satisfaction. (5) Job Satisfaction has a positive and significant effect on the Organizational Commitment of Personnel.
\end{abstract}

Keywords: Job Design, Career Development, Organizational Commitment Job Satisfaction

\section{INTRODUCTION}

In the current era of globalization, where changes occur very quickly, uncertainty is high and competition is fierce so that organizations (businesses) and their employees are required to always improve effectiveness and efficiency. If the leadership of the organization (business) wants to retain its best employees, the organization (business) needs to implement and understand effective HR management. In HR management, one of the goals is that employees/employees commit to the organization.

Kreitner and Kinicki (2014: 165) define organizational commitment as the level at which a person knows the company and its goals. Organizational commitment is built through an identification process in which someone does something from an idea as self-development. An employee who commits will remain with his organization in conditions that are pleasant or not, as experienced by the organization. Employees will remain with their organization in joy or sorrow, attend to work regularly, give 
their entire day (overworking hours), protect company assets, share company goals, and others. A strong organizational commitment will encourage someone to become loyal employees or have high loyalty, to work as well as possible for the benefit of the organization (Widjojo, 2012).

Commitment to the organization means more than just formal membership because it includes an attitude of liking the organization and a willingness to exert a high level of effort for the benefit of the organization in achieving its goals. Organizational commitment is a condition in which an employee participates and strives for his efforts to achieve organizational goals and the desire to maintain his position in the organization (Irvan, 2013).

Employee organizational commitment is shown in an attitude of acceptance, a strong belief in the values and goals of the organization, as well as a strong urge to maintain and become an important part of organizational members to achieve organizational goals (June, 2016).

It cannot be denied that one of the benefits of the commitment that employees have for the organization is that it can help the organization achieve its goals. With high commitment, an employee will love his job and be able to work with a sense of responsibility. In contrast to employees who have a low commitment to their organization. High commitment will spur employees to work as well as possible so that productivity can increase and organizational goals can be achieved. Therefore, high commitment is very important for an organization to achieve the goals that are expected (Amstrong, 2003).

Factors that can affect organizational commitment are job satisfaction. Job satisfaction is one of the reasons for increased organizational commitment, individuals who are satisfied with their work will commit to the organization and vice versa if the individual is not satisfied with their work, it is difficult to commit to the organization (Shah et al., 2012).

Job satisfaction also reflects the degree to which someone likes their job. Defined formally, job satisfaction is an affective or emotional response to various aspects of a person's job. Individuals who are satisfied with their work will have commitment, participation, and attention to the organization in their work. The results of job satisfaction become a constructive approach such as commitment, participation, and organizational attention to work (Khan et al., 2014).

Wexley and Yukl (2003) say that job satisfaction is a generalization of attitudes toward work. The various attitudes of a person towards their work reflect pleasant and unpleasant experiences at work and their hopes for future experiences. A job that is fun to do, it can be said that it gives satisfaction to the shaker. Creating employee job satisfaction in the organization is very important, if employees do not achieve job satisfaction then a negative attitude will arise in the job such as reduced feelings of interest in employees towards their current work.

Studies on the relationship/influence of job satisfaction on organizational commitment have been carried out by many previous researchers including research from Valaei \& Rezaei (2016) were the results of their research found that all dimensions of job satisfaction consist of satisfaction with salary, promotion, supervision, employment, and colleagues. work has a significant relationship with organizational commitment. Likewise, research from Yang (2010) Varona (1996) Testa (2001) Song, Lee, Lee, \& Song, (2015), and Schwepker (2001) found that job satisfaction has a significant effect on organizational commitment.

The level of job satisfaction and organizational commitment of employees can be influenced by the design of the job they are facing. According to Wirawan (2015: 87), "Work design is an integrated job content, qualifications, and rewards for each job in a way that meets the needs of employees and organizations." This means that the work design provides assertiveness and a clear division of tasks that must be achieved by each employee according to their respective divisions. If the division of tasks given is not balanced between one employee and another, it will result in the employee being burdened and this will certainly harm the level of job satisfaction at work so that the work cannot be completed properly.

Simple job design is the determinant of all work to be performed by employees of an organization. According to Handoko (2014) job design is a function of implementing the work activities of an individual or group of employees organizationally. A good job design must be able to reflect job descriptions and job specifications that are tailored to the requirements that are required of the employees who will occupy the position. If the placement of employees is following the demands of the job requirements, then employees tend to be satisfied with their work, because they can carry it out according to their abilities, skills, and requirements demanded by the job.

A poor job design will result in a decrease in employee job satisfaction. The problems that often arise as a result of a lack of good job design are that employees feel that the work they are doing is not following themselves. Employees will feel treated unfairly. A decrease in job satisfaction will result in high work saturation of employees. High levels of saturation will be detrimental to the organization because it will reduce employee productivity. Tamhir, Sujanto, \& Karnati (2019) and Onimole (2015) have found that job design has a significant effect on job satisfaction.

Apart from being influenced by the job design that employees face, the level of job satisfaction and organizational commitment can also be influenced by career development. Career development is needed to manage HR effectively and efficiently. According to Mathis (2006), a career itself is a series of positions related to the work occupied by a person throughout his life. From the beginning of the employee entering the organization (business), an employee should be able to plan his career path while in the organization (business), while the task of the organization (business) is only to facilitate employees and provide information on how an employee achieves his career goals, such as determining certain conditions in the organization (business). take up a certain position. Solihin, Aima, Widyastuti (2019), Febrianti, Suharto \& Wachyudi (2020), found that career development has a significant effect on job satisfaction.

To support the implementation of these tasks, the Directorate of Samapta Regional Police of West Nusa Tenggara needs to be supported by relatively large numbers of human resources, because the phenomena of community life related to security are still not guaranteed, the frequency of cases, especially Covid 19 is continues. Every task that will be carried out and has clear operational procedures, but not all tasks can match all the capacities of the personnel who will carry it out because work conditions can increase due to the sometimes uncertain situation 
In particular, one of the tasks currently very dominant for the Directorate of Samapta Regional Police of West Nusa Tenggara is to carry out activities related to preventing the spread of covid-19. Directorate of Samapta Regional Police of West Nusa Tenggara continues to invite community members to always maintain their health and comply with the appeal from the Government. The chain of spreading this virus will be difficult to break if there is no participation from all elements of society. This activity provides an appeal for the dangers of Covid-19 to be added at the same time as dissolution, because initially, many people still did not understand the dangers of the coronavirus and how to prevent it, such as spraying disinfectant fluids 341 times in West Nusa Tenggara. This includes providing appeals and at the same time dismissing unclear community gathering activities. In this activity, socialization of physical distancing was also carried out to the community.

In practice, taking part in dealing with each mass dissolution is a tough task for the personnel of the Samapta Directorate because until now there are still many layers of society who think the pandemic is just fake news. So it is very difficult to face society like this. It takes work and a high commitment to do it, especially when faced is the society which is a subject that must be served by the personnel themselves.

Based on this description, the objectives of this study can be determined as follows:

1) To analyze the significance effect of Job Design on Job Satisfaction

2) To analyze the significance effect of Career Development on Job Satisfaction

3) To analyze the significance effect of Job Design on the Organizational Commitment

4) To analyze the significance effect of Career Development on the Organizational Commitment

5) To analyze the significance effect of Job Satisfaction on Organizational Commitment.

\section{THEORETICAL}

\section{Organizational Commitment}

Organizational commitment is (1) a strong desire to remain as a member of a certain organization, (2) the desire to try hard following the wishes of the organization, (3) certain beliefs and acceptance of the organization's values and goals. In other words, it shows that organizational members express their concern for the organization and its success and continuous progress (Lutahan, 2005).

Organizational commitment attitudes are determined according to person variables (age, position in the organization, and dispositions such as positive or negative effectiveness) and organization (job design, values, support, and supervisory leadership style) and even non-organizational factors such as other alternatives after deciding to join the organization.

Organizational commitment is defined as a condition in which an employee side with a particular organization and its goals and desires to maintain membership in the organization. So, high job involvement means taking sides with an individual's particular job, while high organizational commitment means siding with the organization that recruits the individual (Robbins and Judge, 2008: 101).

According to Gibson et al (2008), commitment to an organization involves three attitudes: (1) identification with organizational goals, (2) a feeling of involvement in organizational tasks, and (3) a feeling of loyalty to the organization. So that it means that organizational commitment is a form of identification, loyalty, and involvement expressed by employees towards the organization. An employee who has a good commitment means that the employee has loyalty to the organization where he is currently and will try to optimally achieve the goals of the organization where he works.

Organizational commitment according to Ivancevich (2007) is a feeling of identification, involvement, and loyalty expressed by employees towards the organization. Based on this understanding, it can be identified that commitment to the organization involves three attitudes, namely, a sense of identification with the goals of the organization, a feeling of being involved in organizational tasks, and a feeling of loyalty to the organization. Research evidence suggests that the absence of organizational commitment can reduce organizational effectiveness.

Steers and Poter in (Sopiah, 2008) suggest that there are several factors that affect employee commitment to the organization, namely:

1) Personal factors include job expectations, psychological contracts, job choice factors, personal characteristics. All of these factors will form the starting factor.

2) Organizational factors include initial work experience, job scope, supervision, goal consistency organizational, career, job design. All of these factors shape and give rise to responsibility.

3) Non-Organizational Factors which include: the availability of alternative jobs. Is a factor that does not come from within the organization.

Several factors affect commitment, according to Marat (2000) "The commitment of an employee is influenced by several factors such as motivation, compensation, satisfaction, training, a function of leaders, the climate of cooperation, morale and conflicts that occur in an office".

\section{Job Satisfaction}

Locke in Luthans (2006) defines job satisfaction that is the result of career perceptions about how well their job provides things that are considered important. According to Hasibuan (2007), "Job satisfaction is a pleasant emotional attitude and loves his job. This attitude is reflected by work morale, discipline, and performance. "

Handoko (2001) also states, "Job satisfaction is a pleasant or unpleasant emotional state in which employees view their work. Job satisfaction reflects a person's feelings about his job " 
In the opinion of Keith Devis, Wexley, and Yuki, "Job satisfaction is a feeling that supports or does not support an employee concerning his job or his condition. Job-related feelings involve aspects such as wages or salaries received, career development opportunities, relationships with other employees, job placement, type of work, company organizational structure, quality of supervision. While the feelings related to him include age, health condition, ability, education "

Job satisfaction is related to meeting the needs of employees who feel their needs are met will perceive themselves as employees who have satisfaction with their work. Conversely, dissatisfaction arises when one or part of his needs cannot be met. Job satisfaction is one of the determinants of high and low employee performance (Robbins 2007).

\section{Job Design}

Simamora (2004: 116) says job design is the process of determining the tasks to be carried out, the methods used to carry out these tasks, and how the work is related to other jobs in the organization. Job design combines job content (duties, powers, and relationships) remuneration, and required qualifications (skills, knowledge, and abilities) for each job by meeting the needs of employees and organizations. Jobs that are not following skills will be very difficult for employees to carry out. The job design must be designed as well as possible by considering the elements that affect the design of the job.

Handoko (2018: 31) says job design is a function of determining the work activities of an individual or group of employees in an organized manner. Its purpose is to organize work assignments that meet organizational, technological, and behavioral needs. From the perspective of personnel management, job design greatly influences the quality of work-life, which is reflected in the individual satisfaction of officeholders.

Hernando (2001: 110) explains that job design is a breakdown of tasks and ways of carrying out tasks or activities which include who does the task, how the task is done, where the task is done, and how the task is carried out.

Dessler (2004: 104) says that job design is written knowledge about what workers should do, how that person should do, and what the working conditions are. Job design includes job identification, job and job relationship, work standards and authority, job conditions must be clearly described, and an explanation

The purpose of job design is to organize the jobs needed by the organization and is used to motivate and create opportunities for individual officeholders to achieve better performance and obtain job satisfaction. Simamora, (2004) job characteristics models are an approach to job enrichment. Job enrichment programs seek to design jobs in a way that helps job holders satisfy their needs for growth, recognition, and responsibility. Job enrichment adds a source of satisfaction to work. This method increases responsibility, autonomy, and control. Adding these elements to a job is sometimes called vertical job loading.

\section{Career Development}

Career development is basically oriented towards the development of the organization in responding to future business challenges. Every organization must accept the fact that its future existence is dependent on HR (Nawawi, 2006: 98). Without having competitive HR, an organization will experience setbacks and will eventually be excluded due to the inability to face competitors. Such conditions require organizations to carry out career development for personnel, which must be carried out in a planned and sustainable manner.

According to Anoraga (2005: 99), a career in a narrow sense (as an effort to earn a living, develop a profession, and improve one's position), a career in a broad sense (as a step forward throughout life or carve one's life). Meanwhile, according to Handoko (2011: 58) career is all job positions that are handled or held during a person's work life. Sadili Samsudin (2006: 133) defines career development as an effort to improve the technical, theoretical, conceptual, and moral abilities of employees following the needs of the job/position through education and training.

The definition of career development according to Nawawi (2006: 99), career development is a series (sequence) of positions or positions occupied by a person during a certain lifetime. This definition places the position of a worker in an organization, as part of a series of positions occupied during his lifetime.

Mangkunegara (2005), argues that career development is an employment activity that helps employees plan their future careers in the company so that the company and the employees concerned can develop themselves optimally. From some of the definitions of career development above, it can be concluded that career development is an effort to improve the technical, theoretical, conceptual, and moral abilities of personnel according to the needs of the job through education and training.

\section{Conceptual Framework and Hypotheses \\ Relationship between Job Design with Job Satisfaction}

According to Siagian (2011: 98), the design and rebuilding of various jobs are intended so that the implementing workers do not experience boredom which, if it lasts for a long time, can harm one's work life. One of the factors that cause employees to get satisfaction at work is the existence of challenges at the job itself (Widodo, 2015) so that if the job does not have challenges, employees will experience boredom, and job satisfaction will decrease. Therefore, companies need to properly design work designs that will be implemented, where on the one hand employees can carry out their work properly and comfortably without any constraints and on the other hand, the company can achieve goals with work designs that are designed effectively. By considering both sides, The work design that is formed will be carried out properly by employees to jointly achieve company and personal goals. With a working design that has been formed systematically and effectively, employees can work according to their respective portions.

The results of research conducted by Mariono (2012) found that job design contributed and significantly influenced employee job satisfaction. Research conducted by Surina, Pangemanan, \& Tumiwa, (2015) has found that job design has a significant effect on job satisfaction. 
H1: Job Design has a positive and significant effect on Job Satisfaction.

\section{Relationship between Career Development with Job Satisfaction}

Gitosudarmo and Sudipta (2015: 90) write Herzberg's Two-Factor theory related to job satisfaction which is often used at this time in the Two-Factor Theory (Motivator Hygiene Theory). Herzberg argues that workers in carrying out their work are influenced by two main factors which are needs, one of which is the motivational factor which concerns psychological needs related to respect for individuals who are directly related to their work (elements of the job itself) and are a source of job satisfaction. One of these factors is Promotion (Promotion), which is the availability of opportunities to develop in jobs and positions.

Research results from Pratiwi \& Lo (2020) found that career development has a significant effect on job satisfaction. Furthermore, research results from Jusuf, Mahfudnurnajamuddin, Mallongi, \& Latief (2016) found that career development has a significant effect on job satisfaction.

H2: Career Development has a positive and significant effect on Job Satisfaction.

\section{Relationship between Job Design with Organizational Commitment}

Hammer and Avgar (2005) state that employees will tend to leave the organization if they feel they are not following the design and job characteristics. Handoko (2018: 31) says job design is a function of determining the work activities of an individual or group of employees in an organized manner. Its purpose is to organize work assignments that meet organizational, technological, and behavioral needs. From the perspective of personnel management, job design greatly affects the quality of work-life, which is reflected in their job satisfaction and commitment.

Research Tamhir, Sujanto, \& Karnati (2019) found that job design has a significant effect on organizational commitment, and Meyer, Olsen, \& Torsvik, (1996) found that job design has a significant effect on organizational commitment. H3: Job Design has a positive and significant effect on Organizational Commitment.

\section{Relationship between Career Development with Organizational Commitment}

Organizational commitment has a significant share in achieving the goals and objectives of the company that have been set. High work commitment is desired by managers because it can be associated with the expected positive results. High organizational commitment is a sign that an organization is well managed and is basically the result of effective behavior management.

Career development will assist employees in making themselves committed to the organization or company. Whether or not employees in career development will have an impact on work commitment. From the description above, it can be seen that career development influences work commitment where this influence can have a positive impact. the results of previous research conducted by Hidayat (2012) which resulted in career development having a positive and significant effect on organizational commitment.

H4: Career Development has a positive and significant effect on Organizational Commitment.

\section{Relationship between Job Satisfaction with Organizational Commitment}

According to Handoko (2001), Mathis and Jackson (2011) that job satisfaction reflects a person's feelings towards their job, when someone is satisfied with their work they will be more committed to the organization. This is in line with the research of Boles et al. (2007) in several American companies stated that the provision of appropriate salaries and promotions will affect employees' desire to remain loyal to the organization.

Research from Valaei \& Rezaei (2016) where the results of their research found that all dimensions of job satisfaction consisting of satisfaction with salary, promotion, supervision, employment, and co-workers have a significant relationship with organizational commitment. Likewise, research from Song, Lee, Lee, \& Song, (2015) and Schwepker (2001) found that job satisfaction has a significant effect on organizational commitment.

H5: Job Satisfaction has a positive and significant effect on Organizational Commitment.

The following is presented a conceptual framework of research,

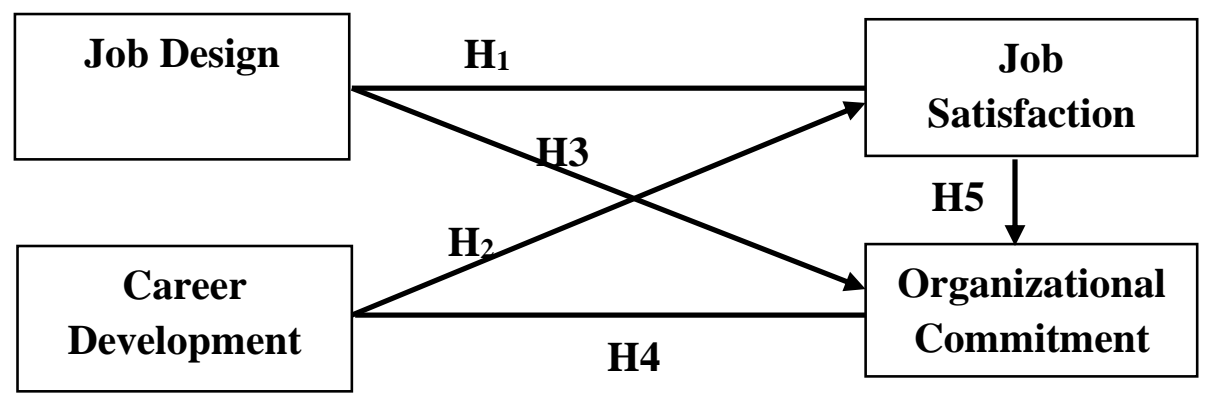

Figure 1. Research Model Conceptual Framework 


\section{METHODS}

The approach in this research used causal associative research. This research was conducted at the Directorate of Samapta Regional Police of West Nusa Tenggara Province. The respondent in this research based on 95 personnel. The data collected by questionnaire. The questionnaire is a list of questions following the indicators of the variables, the aim is to obtain information from respondents about what they feel and know. This study used SEM analysis of Partial Least Squares (PLS). PLSSEM analysis is used following the problems studied, the condition for the number of samples that is not large and does not require normality requirements, and other requirements that are strictly following a variety of parametric statistical approaches. PLS-SEM analysis can work, both on formative indicators and reflective indicators, which in this study are reflective. It means that the indicator seems to be a variable that is influenced by latent variables. This means that if there is a change from one indicator it will result in changes to other indicators in the same direction (Ghozali, 2011).

\section{RESULTS}

\section{Description of Respondent}

Personnel of Samapta in the West Nusa Tenggara Regional Police is dominant in the relative age of 31-40 years. At this age range, it can be called a productive age and has a high physical workforce. This is following the demands of duties in the Ditsamapta environment, which is more dominant in working physically, such as providing security at every demonstration which requires physical fights.

Most of the personnel of Samapta have education at the Senior High School level. Because the Job on Samapta is more dominant and synonymous with physical work, the educational requirements are still senior high school education. Most of the personnel of the Samapta Directorate are men. Predominantly physical jobs are usually required for male personnel compared to female personnel. The personnel of the Samapta Directorate are indeed classified as dominant, still young, and physically strong, therefore this is followed by experience through their relatively under 5 years of service.

\section{Description of Variables}

The average score of Job Design based on the response of the Samapta Directorate Personnel is fairly good category, meaning that the work design carried out and associated with the capacity possessed is felt to be sufficient for the personnel of Samapta. The average score of Career Development based on the respondent's response with a good category, it mean that the opportunity for promotion to be able to occupy the expected position is declared as potential by the personnel.

The average value of the Job Satisfaction with the category less satisfied. This means that the personnel of the Directorate of Samapta are still not satisfied with the five elements related to their work. The average score of Organizational Commitment is a very high category, meaning that the personnel of the Directorate of Samapta have very high pleasure and loyalty to the organization and their work.

\section{Significance Test}

The results of the significance level test can be seen in table 1. summarize the results of hypothesis testing with the PLS approach. The path coefficient value is obtained from the SmartPLS output which can be seen below.

Table 1. Model Structural Test Results

\begin{tabular}{lcccc}
\hline \multicolumn{1}{c}{ Influence Between Variables } & Coefficient & T Statistics & P value & Information \\
\hline Job Design -> Organizational Commitment & 0.197 & 2,150 & 0.016 & Significant \\
Career Development -> Organizational & 0.486 & 3,527 & 0,000 & Significant \\
Commitment & 0.123 & 0.913 & 0.181 & Not significant \\
Job Design -> Job Satisfaction & 0.289 & 2,345 & 0.010 & Significant \\
Career Development -> Job Satisfaction & 0.333 & 2,249 & 0,000 & Significant \\
Job Satisfaction -> Organizational Commitment & & &
\end{tabular}

Based on Table 1, it explains:

1) Job Design has a positive and significant effect on the Organizational Commitment of the Samapta Directorate Personnel at the West Nusa Tenggara Regional Police, indicated by the path coefficient value of 0.197 with a significance value of 0.016 (lower than the error tolerance of $5 \% / 0.05$ ) which means positive and significant so that it can be stated that the first hypothesis is accepted.

2) Career development has a positive and significant effect on the Organizational Commitment of the Samapta Directorate Personnel at the West Nusa Tenggara Regional Police, indicated by the path coefficient value of 0.486 with a significance value of 0.000 which means positive and significant so that it can be stated that the second hypothesis can be accepted.

3) Job Design has a positive and significant effect on the Job Satisfaction of the Samapta Directorate Personnel at the West Nusa Tenggara Regional Police, indicated by the path coefficient value of 0.123 with a significance value of 0.181 (greater than the error tolerance of 5\% (0.05) which means positive and insignificant so that It can be stated that the third hypothesis is rejected. 
4) Career development has a positive and significant effect on the Job Satisfaction of the Samapta Directorate Personnel at the West Nusa Tenggara Regional Police, indicated by the path coefficient value of 0.289 with a significance value of 0.010 which means positive and significant, so it can be stated that the fourth hypothesis is accepted.

5) Job Satisfaction has a positive and significant effect on the Organizational Commitment of the Samapta Directorate Personnel at the West Nusa Tenggara Regional Police, indicated by the path coefficient value of 0.333 with a significance value of 0.013 which means positive and significant, so it can be stated that the fifth hypothesis can be accepted.

\section{DISCUSSION}

\section{The Effect of Job Design on Organizational Commitment}

Research result shows that Job Design has a positive and significant effect on the Organizational Commitment of Personnel. Hammer and Avgar (2005) state that employees will tend to leave the organization if they feel they are not following the design and job characteristics. Handoko (2018: 31) says job design is a function of determining the work activities of an individual or group of employees in an organized manner. Its purpose is to organize work assignments that meet organizational, technological, and behavioral needs. From the perspective of personnel management, job design greatly affects the quality of work-life, which is reflected in their job satisfaction and commitment.

The results of this study reinforce the results of research that have been conducted by Tamhir, Sujanto, \& Karnati, (2019) and Meyer, Olsen \& Torsvik (1996) found that job design has a significant effect on organizational commitment. So are the research results fromKasmiruddin and Armawati (2016), Silen (2016), and Widyanti, Anhar, and Basuki (2020) that job design has a significant effect on organizational commitment.

\section{The Influence of Career Development on Organizational Commitment}

Research result shows that Career Development has a positive and significant effect on Organizational Commitment. Career development will assist employees in making themselves committed to the organization or company. Whether or not employees in career development will have an impact on work commitment. From the description above, it can be seen that career development influences work commitment where this influence can have a positive impact.

Organizational commitment has a significant share in achieving the goals and objectives of the company that have been set. High work commitment is desired by managers because it can be associated with the expected positive results. High organizational commitment is a sign that an organization is well managed and is basically the result of effective behavior management.

The results of this study reinforce the results of research that have been conducted by Solihin, Havidz, Widyastuti (2019), Jusuf, Mahfudnurnajamuddin, Mallongi, \& Latief, (2016), Ogaboh, Nkpoyen, \& Ushie, (2010), Li, Tong, \& Wong, (2014), Nazish, Amjad, Mehboob, Rizwan, \& Sajid (2013), Benson (2003) have found that career development has a significant effect on organizational commitment.

\section{The Influence of Job Design on Job Satisfaction}

Research result shows that Job Design has a positive but insignificant effect on Job Satisfaction. This means that even though the work design is improved, the job satisfaction of the personnel cannot be increased because the personnel's work must meet the specified prototype or Standard Operating Procedure standards.

According to Siagian (2011: 98), the design and rebuilding of various jobs are intended so that the implementing workers do not experience boredom which, if it lasts for a long time, can harm one's work life. One of the factors that cause employees to get satisfaction at work is the existence of challenges at the job itself (Widodo, 2015) so that if the job does not have challenges, members experience boredom, and job satisfaction decreases. Therefore, companies need to design a good work design that will be applied, where on the one hand the members can carry out their work properly and comfortably without any constraints and on the other hand, the organization can achieve its goals an effectively designed work design.

By considering these two sides, the work design that is formed will be carried out properly by employees to jointly achieve company and personal goals. With a working design that has been formed systematically and effectively, employees can work according to their respective portions.

The results of this study are not the same as the results of research conducted by Mariono (2012) which found that job design contributed and significantly influenced employee job satisfaction. research conducted by Surina, Pangemanan, \& Tumiwa, (2015), Abid, Sarwar, Imran, Jabbar, Hannan, (2013), Parvin, 2011), Sageer, (2012), Oghojafor, BA, (2012) and Onimole (2015) have found that job design has a significant effect on job satisfaction.

\section{The Influence Career Development on Job Satisfaction}

Research result shows that Career Development has a significant effect on Job Satisfaction. Gitosudarmo and Sudita (2015: 90) write Herzberg's Two-Factor theory related to job satisfaction which is often used at this time in the Two-Factor Theory (Motivator Hygiene Theory). Herzberg argues that workers in carrying out their work are influenced by two main factors which are needs, one of which is the motivational factor which concerns psychological needs related to respect for individuals who are directly related to their work (elements of the job itself) and are a source of job satisfaction. . One of these factors is the Promotion (Promotion), which is the availability of opportunities to develop in jobs and positions. 
The results of this study also strengthen the results of research that have been conducted by Pratiwi \& Lo (2020), Febrianti, Suharto, \& Wachyudi (2020), Rahayu, Rasid, \& Tannady, (2019), Jusuf, Mahfudnurnajamuddin, Mallongi, \& Latief, (2016) found that career development has a significant effect on job satisfaction.

\section{The Influence Job Satisfaction on Organizational Commitment}

Research result shows that Job Satisfaction has a positive and significant effect on Organizational Commitment. Job satisfaction reflects a person's feelings about their work, when someone is satisfied with their work they will be more committed to the organization. This is in line with the research of Boles et al. (2007) in several American companies stated that the provision of appropriate salaries and promotions will affect employees' desire to remain loyal to the organization.

Hsiao and Chen (2012) in their research conducted at several companies in Taiwan stated that job satisfaction has a significant positive effect on organizational commitment. Research by Luqman et al. (2012) in the public sector in Nigeria stated that employees will be more committed to providing services to consumers when they are satisfied with their work and allowed a career.

The results of this study reinforce the results of research that has been conducted by Valaei \& Rezaei (2016) where the results of their research found that all dimensions of job satisfaction consisting of satisfaction with salary, promotion, supervision, employment, and co-workers have a significant relationship with organizational commitment. Likewise, research from Yang (2010) Varona (1996) Testa (2001) Song, Lee, Lee, \& Song, (2015), and Schwepker (2001) found that job satisfaction has a significant effect on organizational commitment.

\section{CONCLUSIONS}

From the results of the research and discussion above, the conclusions of the research that can be drawn are:

1) Job Design has a positive and significant effect on the Organizational Commitment of Personnel.

2) Career development has a positive and significant effect on the Organizational Commitment of Personnel.

3) Job Design has a positive but not significant effect on the Job Satisfaction of Personnel.

4) Career Development has a positive and significant effect on the Job Satisfaction of personnel.

5) Job Satisfaction has a positive and significant effect on the Organizational Commitment of Personnel.

\section{RECOMMENDATION}

Samapta Directorate personnel is still dominated by high school graduates. It is hoped that the development of personnel can be directed through the provision of educational facilities so that their level of education can be higher which in turn will affect their level of knowledge. The higher their knowledge, the better the way they work so that the achievement of organizational goals becomes easier.

The lowest work design indicator was perceived by the Respondent in the item "Job assignments have clear target results". Current work within the scope of the Directorate of Samapta Regional Police of West Nusa Tenggara is more dominant in securing and directing the public to always pay attention to health protocols. Target work results are very difficult because they deal with the community directly. Regarding internal organizations, work performance descriptions can be a major concern by standardizing work operations more so that each measure of work carried out can clearly have a measure both in quality and quantity.

The item that is perceived to be low concerning the Career Development variable is "clear information regarding career needs and development". Therefore, socialization and direction to members must be optimized again, especially when the dominance of personnel is still at the Senior Haigh School level. It may be necessary to conduct more intense socialization so that they really understand the importance of development in work and career.

In the satisfaction variable item, the item that responded the highest was "The suitability of tasks with knowledge and skills". To increase personnel satisfaction and commitment, work assignments within the Directorate of Samapta Regional Police of West Nusa Tenggara should be adjusted to their knowledge and skills.

The item of the Organizational Commitment variable that is perceived the highest on the item "Moving from one organization to another seems unethical" so that this can be a priority in maintaining and increasing personnel commitment. The doctrines against personnel which are part of the institutional work process within the Police to instill love and sacrifice for the organization have been well accomplished. Of course, this achievement must be maintained and improved in the future so that the attitude and behavior of personnel who are ready to sacrifice are maintained.

\section{REFERENCES}

Abdullah, JW, and Herman, D., (2019), Relationship Between Job Characteristics And Organizational Commitment With Job Satisfaction As Mediating Variable: A Study At Conventional Banks In Ternate, Eurasia: Economics \& Business, 2 (20), February 2019, DOI https://doi.org/10.18551/econeurasia.2019-02

Akhmal, A., Laia, F., \& Sari, RA, 2018, The Influence of Career Development on Employee Job Satisfaction, Journal of Business Administration Volume 07, Number 01, 2018, 20-24. 
Argensia., Et.al (2014), Analysis of the Influence of Job Satisfaction and Motivation on Employee Performance with Organizational Commitment as an Intervening Variable (Study in the Supervision and Service Office of Customs and Excise Type Madya Pabean B Medan), Journal of Economists, 17 (2)

Ariana, IGR, and Mujiati, NW, 2018, The Effect of Job Involvement, Job Characteristics, and Job Satisfaction on Organizational Commitment, E-Journal of Management of Udayana University, Vol. 7, No. 10, 2018: 5314-5342 ISSN: 2302-8912, DOI:https://doi.org/10.24843/EJMUNUD.2018.v7.i10.p5

Benson GS, (2003), Examining employability: Effects of employee development on commitment and intention to turnover. Academy of Management Best Conference Paper, 2003; C1-C6

Boles, J., Madupalli R., Rutherford, B. and Wood JA 2007. The relationship of facets of salesperson job satisfaction with affective organizational commitment. Journal of Business and Industrial Marketing, Vol. 22, No. 5, pp. 311-321.

Chen, TY, Chang, PL, and Yeh, CW (2004). A Study of Career Needs, Career Development Programs, Job Satisfaction and the Turnover Intentions of R\&D Personnel. Career Development International Vol. 9 No. 4 pp. 424-437. Emerald Group Publishing Limited.

Febriansah, RE, 2019, The Effect of Career Planning on Career Commitment and Career Satisfaction through Career Development as an Intervening Variable, Journal of Business, Management and Banking. 5: 1. doi:http://doi.org/10.21070JBMP.V5I1, Volume 5, Issue 1.

Hammer, TH and Avgar, A. 2005. The impact of a union on job satisfaction, organizational commitment, and turnover. Journal of Labor Research, Vol. 26, No. 2, pp. 241-266.

Li, KS, Tong, C., \& Wong, A., (2014), The Impact of Career Development on Employee Commitment of Part-Time Faculty (PTF) in Hong Kong's Continuing Professional Development (CPD) Sector. British Journal of Education, Society \& Behavioral Science. 4. 52-73. 10.9734 / BJESBS / 2014/4810.

Lifter, SE, (1994) Career survey, job satisfaction are you happy in your jobs? Exclusive Report Library J., 119 (18): 44 - 49.

Macintosh, G. and Krush, M. (2014), "Examining the link between salesperson networking behaviors, job satisfaction, and organizational commitment: does gender matter?", Journal of Business Research, Vol. 67 No. 12, pp. 2628-2635.

Mandurah, F., Isharijadi, and Wijaya, AL, 2017, The Effect of Work Environment and Career Development on Job Satisfaction of Dungus Madiun Hospital Employees, The 9th FIPA. Accounting Education Scientific Forum - PGRI Madiun University, Vol. 5 No. 1 Pg. 86-97, Madiun, October 2017, e-ISSN: 2337-9723

Manik E \& Wiharah., (2014)., The Influence of Competence and Compensation on Job Satisfaction and Its Implications on Paramedic Performance at Cibabat Hospital, Cimahi City., Journal of Economics, Business and Entrepreneur., Vol.8., No.2., October 2014.

Mariono, A. (2012). Analysis of the Influence of Job Design and Job Stress on Job Satisfaction and Its Impact on Employee Performance at the Krisbow Department PT. Kawan Lama Sejahtera, https://www.semanticscholar.org/paper/analpentuk-desain-perjaan-dan-stres-kerja-Mariono/efe163b2325fff447b37403e286b8932edc57263

Muhammad Arifin (2017), The Effect of Compensation and Job Satisfaction on Performance (Study of the Faculty of Teacher Training and Education, Muhammadiyah University of North Sumatra), Journal of EduTech Vol. 3 No.2 September 2017, ISSN: 2442-6024, e-ISSN: 2442-7063

Nazish, A., Amjad, R., Mehboob, SAA, Rizwan, M., \& Sajid (2013). Job \& Career Influences on Career Commitment Among Employees Of Banking Sector: The Mediating Effect Of Job Satisfaction \& Organizational Commitment. International Journal of Business and Management Invention. Volume 2 (11). 47-54.

Ogaboh, A., Nkpoyen, F. \& Ushie, E., (2010), Career development and employee commitment in industrial organizations in Calabar, Nigeria. American Journal of Scientific and Industrial Research. 1. 10.5251 / ajsir.2010.1.2.105.114.

Oghojafor, BA, (2012). Assessment of job design and job satisfaction among doctors and nurses in Lagos, Nigeria hospitals. African Journal of Business Management, Vol. 6 (48), pp. 11702-11706.

Putra, EP, 2018, Analysis Of Factors That Affect The Loyalty Of Employee Of PT. Gersindo Mining Plantation Pasaman Barat, e-Journal of Economic Appreciation Volume 6, Number 3, November 2018: 314 - 321 ISSN Print: 2337-3997, ISSN Online: 2613-9774.

Purwanto, BH, and Soliha, E., (2017), The Effect of Job Characteristics and Competence on Performance Through Organizational Commitment, Management Journal / Volume XXI, No. 02, June 2017: 227-240

Reid, MF, Riemenschneider, CK, Allen, MW and Armstrong, DJ (2008), "Information technology employees in state government a study of affective organizational commitment, job involvement, and job satisfaction", The American Review of Public Administration, Vol. 38 No. 1, pp. 41-61.

Silen, AP, (2016), The Effect of Competence and Career Development on Job Satisfaction with Organizational Commitment as a Mediation Variable (Study of Polytechnic Science of Shipping (PIP) Semarang), Journal of Business and Economics (JBE), September 2016, p. 174 - 185 Vol. 23, No. 2.ISSN: 1412-3126

Song, HJ, Lee, H.-M., Lee, C.-K. and Song, S.-J. (2015), "The role of CSR and responsible gambling in casino employees' organizational commitment, job satisfaction, and customer orientation", Asia Pacific Journal of Tourism Research, Vol. 20 No. 4, pp. 455-471 Sumadi, S., Andri, G., \& Yonaldi, S. (2013). The Influence of Job Design and Organizational Commitment on Employee Job Satisfaction at the Padang State Treasury Service Office. Management And Entrepreneurship, 4 (2), 40-56. Retrieved fromhttps://ojs.unitas-pdg.ac.id/index.php/mana Manajemen/article/view/143

Tamhir, L., Sujanto, B., \& Karnati, N., (2019), The Effect of Job Design and Quality of Work Life Toward Affective Commitment of Teachers (September 13, 2019). International Journal of Mechanical Engineering and Technology 10 (3), 2019, pp. 1535-1542, Available at SSRN:https://ssrn.com/abstract=3453133 
Ubadillah, N., Prayitno, A., (2015), The Influence of Leadership, Work Environment, Organizational Commitment and Compensation on Employee Performance (Studies on Employees of Savings and Loans Cooperative (KSP) "Utama Karya" Semarang Branch).

Udayana, KJ., (2015), The Influence of Organizational Commitment on Employee Work Performance of PT. Sekar Nusa Baruna, Singaraja Branch, 2015., Journal of Business and Economics., Vol. 5 No.1

Valaei, Naser \& Rezaei, Sajad. (2016). Job satisfaction and organizational commitment: An empirical investigation among ICTSMEs. Management Research Review. 39.1663-1694. 10.1108 / MRR-09-2015-0216.

Varona, F. (1996), "Relationship between communication satisfaction and organizational commitment in three Guatemalan organizations", Journal of Business Communication, Vol. 33 No. 2, pp. 111-140.

Yang, J.-T. (2010), "Antecedents and consequences of job satisfaction in the hotel industry", International Journal of Hospitality Management, Vol. 29 No. 4, pp. 609-619.

Yusaini (2017), The Effect of Job Satisfaction and Institutional Commitment on Lecturer Performance Iain Langsa, Journal of Islamic Economics and Business, Volume: 2, Number: 1, Pages 1 - 14, Langsa, April 2017, ISSN: 2502-1397, E-ISSN: 2540-8100. 